\title{
THE IMPACT OF CONTINUOUS IMPROVEMENT CONCEPTS ON THE PERFORMANCE OF FURNITURE PRODUCTION PROCESSES
}

\author{
Simanová, L'., Sujová, A.
}

L'ubica Simanová / Technical University in Zvolen, Faculty of Wood Sciences and Technology, Department of Economics, Management and Business, UI. T. G. Masaryka 24, 96001 Zvolen, Slovakia.Email: lubica.simanova@tuzvo.sk

Andrea Sujová / Technical University in Zvolen, Faculty of Wood Sciences and Technology, Department of Economics, Management and Business, UI. T. G. Masaryka 24, 96001 Zvolen, Slovakia.Email:sujova@tuzvo.sk

\begin{abstract}
Most small and medium-sized enterprises in the furniture industry use simple partial approaches to improve or manage production processes. The article aims to present research results focused on continuous process improvement through the implementation of Six Sigma (SS) and Lean Six Sigma (LSS) concepts in furniture production. Their impact on the performance via the level of the ROE (Return on Equity) indicator was evaluated using statistical methods of Chi-square test and Cramer's contingency coefficient. The results of the research showed that furniture enterprises that had implemented selected methods of quality management reached a medium level of ROE values. The absence of a more comprehensive approach to managing the performance of processes was the impulse for a model creation based on the interconnection of SS and LSS concepts. The model should a practical use of appropriate methodologies and procedures in the management of furniture production processes, as well as in their optimisation. A thorough analysis of nonconforming products performed in furniture manufacturing processes transformed into SS and LSS metrics and the implementation of the model in the enterprise led to reduced process waste by reducing the number of non-conforming products, reducing the cost of such products, and increasing the capability of critical processes.

Implications for Central European audience: The combination of theoretical knowledge in performance management and quality of production processes and practical knowledge from the real implementation of methods and tools for continuous improvement of production process capability in the company proved to be a good basis for creating a model within SS and LSS. These facts have contributed to the development of scientific knowledge. The presented application of methods and tools within SS and LSS will provide instructions for the use of new management methods. The specific outputs of the research work improve defining problems, measuring process parameters, analysis of measured data, improving furniture production processes.
\end{abstract}

Keywords: process capability; performance; furniture production; Six Sigma; Lean Six Sigma

JEL Classification: L23, M11 


\section{Introduction}

Business management is influenced by changes in the macro and microenvironment, which raises the need to modify existing traditional methods in managing the quality and performance of processes and their subsequent optimisation. The management decisions themselves can be based on qualitative or quantitative data. It is these data that play an important role in the appropriate selection of concepts, methods, and tools in their proper implementation and application of solutions to specific problems in processes. Process performance management methods are focused on correct tuning the capability and variability of processes. The choice and use of a particular method depending on the nature and complexity of the processes. An important attribute in the selection of methods is also the selection of suitable process characteristics, which create a unified data platform for comparison by transformation into indicators. Recent studies in the industry and services, such as Inal Tamer et al. (2018) report that process performance is improved through Six Sigma. Smetkowska and Mrugalska (2018) present a case study aimed at improving the quality of production processes and improving performance. Similarly, Marzagão and Carvalho (2016) and Ambekar and Hudnurkar (2017) consider financial and time constraints to be the main obstacles to organisational resources in implementing Six Sigma. Although Lean Six Sigma has its roots in manufacturing, it is proven to be a wellestablished process excellence methodology in almost every sector despite its size and nature. This includes sectors like healthcare (Gijo \& Antony, 2014), higher education (Antony et al., 2018), public sector organisation (Antony et al., 2017a), Police Force (Antony et al., 2017b), food industry (Dora \& Gellynck, 2015). Moreover, several small and mediumsized enterprises have shown some remarkable results from the adoption of LSS as a business process excellence methodology (Antony et al., 2016). Kumar et al. (2006) presented a case study focused on the implementation of LSS in Indian small and medium enterprises; Sunder (2013) focused on the application of LSS in the banking sector to reduce the number of rejections in the field of customer service. Gijo and Antony (2014) improved the waiting time of patients in the outpatient department of a specialised hospital using LSS. Gijo and Sarkar (2013) discuss the use of Six Sigma in road construction, and Laureani et al. (2010) increased the resolution ratio of the first call in the call centre using LSS. The authors of Pamfilie et al. (2012) and McLean et al. (2017) agree that many industries have adopted the LSS methodology for continuous improvement, but its implementation is not immune to failure. According to Snee and Hoerl (2007) and Choo (2019), the main problem in the implementation of LSS or SS projects is resistance to implementation due to a general distrust in the effectiveness of these projects. Laureani and Antony (2019) see leadership as a key factor in the success of SS and LSS implementation.

The purpose of the article was to fill a gap in research of process improvement through the implementation of SS and LSS concepts in processes representing furniture production and awareness of the benefits, but also the limitations of their implementation. The combination of theoretical aspects of the problem and the practical implementation of the SS and LSS model in the conditions of furniture production allowed us to take a critical look at the extraordinary situations occurring in the industry. The importance of the issues presented in the article through observations, suggestions, and recommendations from the implementation of the SS and LSS model could be a valuable contribution to improving quality processes and increasing enterprises' performance. 
The furniture industry in Slovakia consists mainly of micro-enterprises, small and mediumsized enterprises. It has a long tradition and provides environmental and economic benefits based on the use of renewable resources, and it is one of the supported and promising sectors due to the support of the European Union.

The article is to present the model of SS and LSS implementation, to point out the possibilities of using the methods and tools to improve quality in furniture processes, to draw attention to success and failure factors of implementation in the furniture industry.

The article contains a review of the literature focused on the use of concepts of continuous process improvement through the concepts of SS and LSS, their implementation successes and failures, as well as their mutual comparison. The second part focuses on the methods used in the analysis of the results of primary quantitative research, verification of hypotheses, and the creation of a model for the application of methods and tools for improvement of the quality furniture processes. The third part presents the results of primary quantitative research, verification of hypotheses, and a model of application of the methods and tools for managing the quality of furniture processes. The fourth part contains a discussion on the issue of using the concepts of SS and LSS. At the end of the article, the contributions to the development of scientific knowledge in the field of continuous quality improvement and increasing the performance of production processes using SS and LSS concepts in specific conditions of furniture production, practical contribution, possibilities of using its results and direction of further research are presented.

\section{Literature review}

A common feature of business processes is that their output is a product or service that is intended for an internal or external customer. Fullerton et al. (2014) and Swarnakar and Vinodh (2016) reported that production organisations are still adopting quality improvement approaches such as Total Quality Management (TQM), Lean Manufacturing (LM) and Six Sigma. Managing quality is at the core of operations strategy (Anand \& Gray, 2017; Hitt et al., 2016). The Six Sigma concept of Six Sigma helps to achieve customer satisfaction through the elimination of defects. The goal of the Six Sigma methodology is to reduce the process variability and produce less than 3.4 defects per million opportunities (DPMO), which makes it an attractive proposition for production managers (Mustafa \& Jamaluddin, 2017; Rizuti \& de Napoli, 2018). Six Sigma is a methodology that highlights the variation in the manufacturing process and helps to reduce them through their statistical tools and techniques (Vinodh \& Swarnakar, 2015). Six Sigma is a data-driven process improvement methodology used to achieve stable and predictable process results by reducing process variations and defects (Laureani \& Antony, 2017). Six Sigma statistical methods provide a structured approach for identifying the root causes of production defects (Schroeder et al., 2008). Six Sigma methods can be implemented by two different strategies Define, Measure, Analyse, Implement, Validate (DMAIC) and Define, Measure, Analyse, Define, Validate (DMADV). DMADV deals with new product development while DMAIC (Kumar et al., 2011; Sachin \& Dileeplal, 2017) is used to bring improvements in existing products or processes.

According to Vest and Gamm (2009), Chow and Moseley (2017), the success factors of the project are presented by the connection of SS projects to the company's business objectives, further, connection with key performance indicators, and quality costs. They also consider critical to the success - the involvement of top management with sufficient 
influence, the security of resources, access to reliable data, completion of the project within a set time limit, use of statistical tools and information technology, and human resources. According to Sony et al. (2020), the limiting factor of universal access to SS can be the access of employees and their creativity. Employees can consider the SS process as suffocating. At the same time, it is difficult to use experimental methodologies within the SS. Their implementation without adaptation to the environment may be another factor of failure. Garcia-Alcaraz et al. (2017), for example, conducted an analysis to combine human factors with operational benefits. Based on the assumption that Six Sigma is a philosophy related to human resources and that it depends on management decisions, supporting organisational structure, and implementation strategy, we can state that the implementation of the Six Sigma concept is strongly influenced by the level of soft skills of human resources.

Montgomery (2016) claims that some companies have not achieved the same success in implementing the Six Sigma methodology, which has led to unnecessary costs, loss of time and money. The reasons for failure are insufficient understanding of the concept and scope of the methodology, insufficient education and training, poor management strategies and lack of supportive organisational structures (Nourelfath et al., 2016). Brun (2011) and Desai et al. (2012) found that Six Sigma's success varied based on company size. The authors of Kumar et al. (2014) found that the absence of activities related to the lead manager, as well as the subsequent misunderstanding of the Six Sigma project by other team members, was the main cause of the failure. Another cause of failure was identified by Marzagão and Carvalho (2016), a factor associated with the use of statistical tools and information technology, as well as the need for smaller projects to ensure the completion of the Six Sigma project in the right timeframe. Chakravorty (2009) report a negative impact on customer and employee satisfaction, adding that the benefits of Six Sigma programs are marginal, and the cost of implementing Six Sigma is more than its benefits. Further reports and analyses of critical success factors for Six Sigma can be found in the work of Mustafa and Jamaluddin (2017), Alhuraish et al. (2017), Marzagão and Carvalho (2016), and Psomas (2016).

Snee (2010) defines Lean Six Sigma as a business strategy and, at the same time, a methodology that increases the process performance. Vinodh et al. (2014) and Youssouf et al. (2014) define Lean Six Sigma as a combination of tools and techniques that reduce variability and build on Six Sigma tools and methods for eliminating waste and added value. LSS is a method of improving quality and profitability based on mastering the stability of the process, and it is also a management style that is based on a highly regulated organisation dedicated to project management. LSS has been used with great success not only in the manufacturing sector but also in healthcare (Laureani \& Antony, 2015) and education (Thomas et al., 2009). Most LSS implementation projects focused on the systematic and consistent application of Six Sigma with a focus on the DMAIC approach, the identification of processes and the specification of solutions that are offered through the effective use of many Lean and Six Sigma tools, such as DOE (Design of Experiments), VSM (Value Stream Mapping), VoC (Voice of Customers), CTQ (Critical to Quality), ToC (Theory of Constraint), SIPOC process map and 5 S method (Gnanaraj et al., 2012, and Vinodh et al. 2012). According to Snee and Hoerl (2007), the results of LSS implementation are expected to reduce costs in the form of direct work, as well as time and effort to perform non-value-added tasks. 
Albliwi et al. (2014) had provided one of the most extensive studies on limits in the implementation of Lean Six Sigma from a renowned database in the field between 1995 and 2013. They identified the top five factors, which are lack of top management attitude, commitment and involvement, lack of training and education, poor project selection, weak link towards the strategic objective and lack of resources. Sunder (2013) analysed the top barriers in deploying Lean Six Sigma. A Pareto analysis pertaining to the reason for failure displayed the top four factors, which include lack of top management involvement, wrong selection of projects, narrow perspectives on projects and lack of ownership on the deployment. According to Bryan et al. (2019), there remains a gap in understanding why organisations select to deploy only Lean or only Six Sigma and doing so may potentially limit the full realisation of benefits generated from continuous improvement efforts. It may be that the selection is based on their business strategy, sense of urgency, the extent to the degree of benefits to be accrued from different $\mathrm{Cl}$ strategies, nature of the problem to be tackled, their vision of continuous improvement or their definition of value. The selection is often more random and based on the preference or knowledge of an individual, the advice of a single consultant or even the only methodological option known to the organisation and, therefore, adopted by default.

Salah et al. (2010) can be seen a different perspective on the success of Six Sigma projects that have been achieved by including Lean principles and tools in the implementation of Six Sigma. The DMAIC cycle is used to implement both Six Sigma and Lean Six Sigma. At each stage, special attention is paid to the application of specific tools. The authors state that the application of tools as well as the choice of methods differs from the type of project and the type of process. The use of a combination of Six Sigma and Lean Six Sigma may cause companies to prioritise certain improvement initiatives, while LSS may solve this problem because, as George (2003) writes, activities that cause critical customer problems and create the longest delays in any area of the process. According to authors Schroeder et al. (2008) and Laureani and Antony (2017), the integration of Lean and Six Sigma was to design a methodology as a coherent approach for continuous improvement. LSS can be differentiated from other quality management approaches due to the organisation and structure of the quality implementation functions. With LSS, such thinking changes, and quality becomes the responsibility of everybody. LSS introduced a formal organisational infrastructure for different quality implementation roles, borrowing terminology from the world of martial arts to define hierarchy and career paths.

The European Union (EU) has put special emphasis on economic development based on renewable resources. For this reason, the furniture manufacturing industry is a fast-growing industry supported by the EU (Sujová et al., 2015a). It provides economic, environmental, and social contributions based on the utilisation of renewable, domestic resources (Potkány et al., 2018). Furniture companies are the most modern and active in the area of innovation, and current policies of national governments prefer furniture manufacturing using domestic sources of wood raw material (Ratajczak, 2009). Previous analyses of several authors (Hlaváčková \& Šafařík, 2014; Han et al., 2009; Ratajczak-Mrozek \& Herbeć, 2014) led to conclusions that furniture manufacturing industry has a high export performance compared to other sectors of industry. 


\section{Materials and methods}

Based on the study and analysis of scientific knowledge in the field of improving the quality production processes, a proposal of this research was compiled. Two methodologies were used in the research: primary quantitative survey and the case study research approach.

The aim of a quantitative survey was to find out the relationship between using continuous process improvement methods and corporate performance in furniture enterprises (if enterprises using modern methods of continuous process improvement are reaching higher corporate performance represented by indicator ROE). Similar research provided by Tuček and Zámečník (2007), Sujová and Marcineková (2015b) revealed that modern management methods within process management have a positive impact on corporate performance.

A case study aims to show the effects of Six Sigma and Lean Six Sigma concepts on financial and process quality results. According to the research of de Koning et al. (2008), strategies LSS used by companies to avoid competitive disadvantages represent savings in the banking sector of the order of $20 \%$ or more of total banking industry costs. Financial benefits after implementation of LSS on companies Sigma General Electric added \$2 billion in 1999 and $\$ 2,4$ billion in 2000 to the bottom line. Honeywell (former Allied Signal) reduced costs by \%1,4 billion from 1992 through 1996; reduced new product introduction time by $16 \%$. DuPont saved $\$ 1,6$ billion in four years; reduced environmental impact. Johnson Controls For the Ohio manufacturing plant: reduced defects by $70 \%$; reduced costs $\$ 800,000$ per year. For the automotive operations in Michigan: saved $\$ 943,000$ per year through greater engineer productivity (Dumitrescu \& Dumitrache, 2011).

The common research question for both methodologies in the research was stated: Modern methods of continual process improvement within SS and LSS concepts contributes to a business performance increase. Additionally, the research hypotheses for each methodology were stated separately.

The first part of the research is a primary quantitative survey in enterprises. Relevant data from the use of concepts, methods, and tools to improve the quality and increase the process performance in enterprises with furniture production in the Slovak Republic were obtained through an online research questionnaire. A database of 259 furniture enterprises was used for the research, of which 102 respondents represent a research sample. The questionnaire consisted of 4 general classification questions related to the number of employees, the main subject of activity, ownership, and the amount of the ROE indicator. Other questions concerned the core of research, namely the preferred processes in terms of improvement of processes and the use of concepts, methods, and tools for process improvement. The questionnaire was published online, and data collection took place in the second half of 2019. This paper analyses the partial results of a questionnaire survey of enterprises in the furniture industry in Slovakia. The evaluation of the questionnaire was carried out by mathematical and statistical methods using the software program STATISTICA 12 CZ - Stat Soft. Inc. (2013). Descriptive statistics, contingency tables, and methodology, according to Rimančík (2007), were used for the statistical analysis. According to Pacáková et al. (2018), Pearson's Chi-Square and Cramer's contingency coefficients were used to test the hypotheses.

The following hypothesis was established and tested in the questionnaire survey: 
$H 1$ There is a relationship between the height of the ROE indicator and the use of concepts, methods, and tools to improve the quality and management of process performance.

The following factors were critical in the selection of the enterprise for the case study: the main activity of the enterprise is the production of furniture, the enterprise produces such an assortment of furniture, the production of which can take place in any furniture company, and all stages of furniture production take place in one enterprise. These factors were considered important to be able to work with as many processes as possible when creating a model, which is representative of the production of different types of furniture. Moreover, the enterprise has implemented certified systems. The enterprise has been operating on the market for a long time; the enterprise has a higher level of process management and the existence of low-level process structure; the enterprise uses at least standard indicators to measure process performance such as degree of failure, cost of non-conforming products; etc., the enterprise provides information and the possibility to perform measurements to create analyses and a model.

By comparing the determined average values of DPMO, efficiency and Sigma level in the processes of the selected furniture enterprise, a critical process with the worst results was identified. The main part of the research was focused on creating the SS and LSS with a combination of selected methods and tools models for solving the problems of quality and process performance. Within the mentioned methodologies and the DMAIC cycle, the following methods and tools listed in Table 1 were used for model creation.

Table 1 | Design of methods and tools for creating a SS and LSS model

\begin{tabular}{lc}
\hline Steps & Selected concepts, methods, and tools \\
\hline Define & $\begin{array}{c}\text { VOC, QFD, furniture production process map, analysis of non-conforming } \\
\text { products in production processes, DPMO, efficiency, and level of sigma } \\
\text { processes for critical process selection, brainstorming, graphical methods of } \\
\text { descriptive statistics, histogram, Pareto diagram, SIPOC map, Project charter } \\
\text { Data collection forms, measurement plan according to Pande et al. (2002), } \\
\text { capability indices, histogram, methods of analysis and synthesis, methods, and } \\
\text { tools of descriptive statistics }\end{array}$ \\
Analyse & $\begin{array}{c}\text { Brainstorming, Decomposition of causes of non-conforming products - Ishikawa } \\
\text { diagram }\end{array}$ \\
Improve & $\begin{array}{c}\text { Report 8D, process reaction plan, 5S method, data collection forms, } \\
\text { measurement plan according to Pande et al. (2002), capability indexes, } \\
\text { histogram, methods of analysis and synthesis, methods, and tools of } \\
\text { descriptive statistics, 5S method, VSM }\end{array}$ \\
\hline
\end{tabular}

Source: own processing

The DPMO, efficiency, and sigma level of processes

DPMO denominates the number of defects that occur per one million opportunities at the development or manufacturing of a product and can be calculated according to the following formula:

$D P M O=\frac{\text { number of defect products }}{\text { total number of products } * \text { number of opportunities per defect }} * 10^{6}$

To calculate the efficiency, the following function was defined in the Statistica CZ program:

$E=1-D P M O / 1000000) * 100$

and for the sigma level =V Normal (1-DPMO/1000000; $1 ; 5 ; 1)$ 
The capability of processes was tested by capability indices. Their calculations generally assume that the process is stable, observations are statistically independent, and have a normal distribution.

The capability index $\mathrm{Cp}$ is an indicator of the potential capability of the process and characterises the variance of the process (Terek \& Hrnčiarová, 2004).

$\mathrm{C}_{\mathrm{p}} \bullet \frac{\mathrm{USL} \text { RLSL }}{6 \sigma}$

where USL - upper tolerance value

LSL - lower tolerance value

$\sigma$ - standard deviation

$6 \sigma-$ means $3 \sigma$ to the left and $3 \sigma$ to the right of the target value T

The critical capability index $\mathrm{Cpk}$ is an indicator of the current process capability and characterises not only the variability of the monitored quality feature but also its position concerning the defined tolerance area.

$\mathrm{C}_{\mathrm{pkUSL}} \bullet \frac{\mathrm{USL} \ell \overline{\overline{\mathrm{X}}}}{3 \sigma}$

$\mathrm{C}_{\mathrm{pkLSL}} \bullet \frac{\overline{\mathrm{X}} \ell \mathrm{LSL}}{3 \sigma}$

where USL - upper tolerance value

LSL - lower tolerance value

$X$ - average value of averages in subgroups

$\sigma$ - standard deviation

The capability index $\mathrm{Cp}$ and the critical capability index Cpk, which consider the average values and the variance of the process, express the ability of the process to meet the customer's requirements. The methodology of calculations was performed according to the authors Terek and Hrnčiarová (2004) and Nenadál and Plura (2008).

Authors Terek and Hrnčiarová (2004), Nenadál et al. (2005), and Pande et al. (2002) recommend the use of control diagrams for statistical process control as a means of operative defining the concept of a stable process. They assume that while processes remain within the limits of regulation, variability has arisen under the influence of common causes. However, if the observation proves otherwise, it is necessary to pay more attention to the observation to reveal the causes of the deviations.

The following hypotheses were determined and tested in the application part, a case study of the research in the selected enterprise:

H2 The implementation of selected concepts, methods, and tools to improve the quality will have a positive impact on the parameters of the critical process.

H3 There is a significant relationship between the critical parameters of the furniture manufacturing process and its performance. 
The $\mathrm{H} 2$ hypothesis was verified by evaluating changes in the values of critical process performance indicators (DPMO, efficiency, and sigma level) and by economically evaluating changes in the cost of non-conforming products.

Verification of the $\mathrm{H} 3$ hypothesis was performed by a paired T-test, which was chosen as a suitable tool for comparing the dependent values of variables according to the methodology of Merkechová et al. (2011). In the first case, it was the diameter of the hole measured before and after the change, i.e., before and after the implementation of corrective measures. Two quantitative features were observed: $X$ - the diameter of the holes and $Y$ the efficiency of the critical process before and after the corrective measures, which were not considered independent. Statistical evaluation was performed using the software program STATISTICA 12 CZ - Stat Soft. Inc. (2013), where the imported database was created in MS Excel. Box graphs are used to graphically illustrate the results.

\section{Results}

\subsection{Results of the primary quantitative research}

The primary quantitative research was carried out in the form of a questionnaire in 102 furniture enterprises. The questionnaire research was focused, among other things, on determining the dependence of the height of the ROE indicator in connection with the use of concepts, methods and tools for continuous improvement quality of furniture production processes.

In a questionnaire survey of 102 furniture companies, it was found that Six Sigma uses 2.94\%, Lean Six Sigma 3.92\%, TQM 35.29\%, process controlling 25.49\%, Kanban 15.69\%, Kaizen 23.53\%, Brainstorming 62.75\%, Poka - Yoke $3.92 \%$, Methods $5 S$ uses 13.73\%, Traditional quality management tools $11.76 \%$, New quality management tools $8.82 \%$, Process capability indices $6.86 \%$, and Statistical process control $15.69 \%$. It is clear from the research that furniture companies have the knowledge and are familiar with the methods and tools used to increase performance within Six Sigma and Lean Six Sigma.

The essence of hypothesis $\mathrm{H} 1$ was whether the implementation of selected concepts, methods and tools for quality improvement and process performance management would have a positive impact on the height of the ROE indicator. The results of the questionnaire research were processed by the Chi-Square test and the Cramer contingency coefficient, through which the intensity of dependence between the use of selected concepts, methods, and tools and the height of the ROE indicator was determined. The test results are shown in Table 2.

The methods included in the survey presented in Table 2 can be briefly described as follows. Six Sigma and Lean Sigma methods, their limitations and success factors were described in the literature review in detail. The Total Quality Management philosophy seeks to integrate all organisational functions to focus on meeting and overcoming customer requirements and organisational goals. TQM also satisfies customers (external and internal) by continuously meeting their expectations, as it involves everyone in the organisation to work on the continuous improvement of all products or processes through a problem-solving methodology. It is organised through quality circles on a voluntary basis and quality improvement teams (Yusuf et al., 2007). Kanban means card in Japanese. In a Kanban system, cards are used systematically to control the production within stations and 
the movement of parts between stations. It is used to effectively control work-in-process (WIP) inventory levels. In the production and operations world, there exist various types of Kanban and optimisation approaches. The original concept of Kanban has four components: use of two communication signals (dual card Kanban system), pulled production, decentralised control, and limited work in process (Krishnaiyer \& Chen, 2017). Kaizen is a continuous process of long-term, lasting, and smooth changes for the better, which are not immediately visible in the processes. The system depends on the involvement of all employees in the improvement and their motivation for its implementation in the detection and elimination of all forms of waste. The philosophy of internal dissatisfaction with the current situation should be based mainly on management. Factors of unsuccessful implementation were summarised in his publication Košturiak et al. (2010) into the following factors: insufficient understanding, poor implementation and insufficient information by management, the reluctance of employees, insufficient understanding of the Kaizen system by employees and their insufficient motivation. Brainstorming is one of the techniques to support group creativity, through which members share ideas and thoughts spontaneously to achieve solutions to practical problems (Gogus, 2012) that the process involved in the task of creating ideas can potentially play an exceptional role in stimulating the ability of individuals to produce creative solutions that can be further evaluated and possibly applied in practice. Usable in all phases of DMAIC, at all levels of process management and in solving problems in processes through a team (Michinov, 2012). Poka-Yoke is a system for eliminating the possibility of errors from human inattention. It is a low-cost and highly reliable method used in the Jidoka system, which stops the process and preventively protects production from failures. It is a procedure that allows you to perform an activity in only one possible style, thus eliminating the possibility of doing something wrong directly in the process. The error is rectified at the beginning by checking according to a sensor located at the end of the process when the error is detected by the worker and by sensors that ensure an immediate stop of the operation when an error is detected (Lazarevic et al., 2019). Process controlling is one of the more demanding management tools that can improve the economic result and especially support the long-term success of the company. Managing a business means managing its processes, especially to control the costs of those processes. Optimal process costs create a precondition for achieving optimal company profit. Managing a business means managing its processes, especially to control the costs of those processes. Optimal process costs create a precondition for achieving optimal company profit. Methods $5 \mathrm{~S}$ is used as one of the management system solutions for establishing and maintaining a quality environment in the company to improve the working environment in the company and thus the quality of products and services. The $5 \mathrm{~S}$ method is based on increasing the independence of employees, on the correct management of people and on team cooperation (Papulová et al., 2014). Process capability indices are described in methods. The use of the STATISTICA program for various large furniture companies is, from the point of view of the use of methods and tools within the SS and LSS, a necessary tool not only for the calculation of $\mathrm{C}_{\mathrm{p}}$ and $\mathrm{C}_{\mathrm{pk}}$, but also other graphical representations. Traditional and new quality management tools and Statistical process control are commonly used methods in managing the performance of business processes. 


\begin{tabular}{|c|c|c|c|c|}
\hline \multirow{2}{*}{ ROE and method } & \multicolumn{3}{|c|}{ Chi-Square test (df-degree of freedom $=5$ ) } & \multirow{2}{*}{$\begin{array}{c}\text { p- significance } \\
\text { level }\end{array}$} \\
\hline & $\begin{array}{l}\text { Pearson Chi- } \\
\text { Square test }\end{array}$ & $\begin{array}{c}\text { Contingency } \\
\text { coefficient }\end{array}$ & Cramer V & \\
\hline Six Sigma & 21.79 & 0.42 & 0.46 & 0.000 \\
\hline Lean Six Sigma & 20.17 & 0.41 & 0.45 & 0.001 \\
\hline TQM & 42.85 & 0.54 & 0.65 & 0.000 \\
\hline Process controlling & 25.03 & 0.44 & 0.49 & 0.000 \\
\hline Kanban & 14.08 & 0.35 & 0.28 & 0.115 \\
\hline Kaizen & 8.48 & 0.37 & 0.29 & 0.132 \\
\hline Brainstorming & 10.90 & 0.31 & 0.33 & 0.053 \\
\hline Poka-Yoke & 5.39 & 0.22 & 0.23 & 0.369 \\
\hline Methods 5S & 6.98 & 0.25 & 0.26 & 0.222 \\
\hline $\begin{array}{l}\text { Traditional quality } \\
\text { management tools }\end{array}$ & 24.47 & 0.44 & 0.49 & 0.000 \\
\hline $\begin{array}{c}\text { New quality } \\
\text { management tools }\end{array}$ & 31.25 & 0.48 & 0.55 & 0.000 \\
\hline $\begin{array}{c}\text { Process capability } \\
\text { indices }\end{array}$ & 19.86 & 0.40 & 0.44 & 0.000 \\
\hline $\begin{array}{c}\text { Statistical process } \\
\text { control }\end{array}$ & 21.89 & 0.42 & 0.46 & 0.000 \\
\hline
\end{tabular}

Source: own processing

Table 2 presents the results of the analysis using the Chi-Square test, which showed that the p-value was higher than 0.05 using Kanban, Kaizen, Brainstorming, Poka-Yoke, and the $5 \mathrm{~S}$ method. We did not reject the $\mathrm{HO}$ hypothesis in the above cases, and we can conclude from this that the height of the ROE indicator did not depend on their use. In the analysis of the use of LSS, SS, TQM, process controlling, traditional and new quality management tools, process capability indexes and statistical process control, the p-value was less than 0.05 , based on which hypothesis $\mathrm{H} 0$ was rejected and the alternative hypothesis $\mathrm{H} 1$ accepted: There is a dependence between the height of the ROE indicator and the use of concepts, methods, and tools to improve the quality and management of process performance.

Cramer's $V$ values using Lean Six Sigma $(V=0.45)$, Six Sigma $(V=0.42), \operatorname{TQM}(V=0.65)$, process controlling $(\mathrm{V}=0.49)$, traditional quality management tools $(\mathrm{V}=0.49)$, new management tools qualities $(\mathrm{V}=0.55)$, competency indices $(\mathrm{V}=0.44)$ and statistical SPC process control methods ( $\mathrm{V}=0.46$ ) indicated a moderate contingency as they ranged from 0.3 to 0.8 . In summary, no statistically significant dependencies were found, so we analyzed the individual concepts, methods, and tools of process performance management separately.

Hypothesis $\mathrm{H} 1$ The relationship between the height of the ROE indicator and the use of concepts, methods, and tools for quality improvement and process performance management is not confirmed. 
The results of the analysed using the Chi-Square test do not allow us to make generally valid statements. Based on the obtained results, we can formulate the assumption that $73.53 \%$ of the analysed furniture enterprises reached the average height of ROE performance indicators. The investigated dependence was confirmed only using selected concepts, methods, and tools such as LSS, SS, TQM, process controlling, traditional and new quality management tools, process capability indexes and SPC. The results of the analysis pointed to reserves in the use of modern methods and approaches in the processes of furniture production. These conclusions confirmed the intention to design a model for the application of concepts, methods and tools for continuous improvement of the quality of furniture production processes.

\subsection{The selection of a furniture enterprise for the application of the proposed model and identification of the critical process}

An important aspect of the second part of our research was the selection of a furniture enterprise for the application of the proposed model and the identification of a critical process. The factors based on which the enterprise was selected met by an enterprise that has been operating in Slovakia since the 1990s with the participation of foreign capital. The enterprise employs over 250 employees. The enterprise has a certified Quality Management System according to ISO 9001, an environmental management system according to ISO 14001, Occupational health and safety management system according to ISO 4500, and an Information security management system according to ISO / IEC 27001. The company is representative of furniture production and its comprehensive process framework.

Based on the comparison of the average DPMO values, efficiency, and sigma level of the furniture production processes listed in Table 3, we can state that the critical process with the lowest value of the sigma level is the holes drilling process.

Table 3 | Comparison of average values of DPMO, efficiency, and sigma level

\begin{tabular}{cccc}
\hline $\begin{array}{c}\text { The processes of } \\
\text { furniture production }\end{array}$ & $\begin{array}{c}\text { The average values } \\
\text { of DPMO }\end{array}$ & $\begin{array}{c}\text { The average } \\
\text { efficiency \% }\end{array}$ & $\begin{array}{c}\text { The average level of } \\
\text { Sigma }\end{array}$ \\
\hline $\begin{array}{c}\text { Division and } \\
\text { calibration }\end{array}$ & 7557.42 & 99.24 & 3.94 \\
Pressing & 139895.64 & 84.07 & 2.61 \\
$\begin{array}{c}\text { Bonding of side } \\
\text { surfaces }\end{array}$ & 1653.98 & 99.82 & 4.52 \\
$\begin{array}{c}\text { Drilling holes } \\
\begin{array}{c}\text { Surface treatment } \\
\text { of side surfaces }\end{array}\end{array}$ & 224249.17 & 77.57 & 2.30 \\
$\begin{array}{c}\text { Surface treatment } \\
\text { of parts }\end{array}$ & 16365.07 & 98.36 & 3.66 \\
$\begin{array}{c}\text { Completion and } \\
\text { pre-assembly }\end{array}$ & 2741.13 .55 & 99.05 & 3.88 \\
Packing & 23131.39 & 99.42 & 4.30 \\
\hline
\end{tabular}

Source: own processing 


\subsection{The verification of hypothesis $\mathrm{H} 2$}

Selected methods and tools within the concept of Six Sigma and Lean Six Sigma and their implementation in the production processes of a particular furniture enterprise are described in Table 1. By evaluating the implementation results and the suitability of the selection of methods and tools based on specific examples given in the design of SS and LSS project for the critical process of drilling holes on furniture parts, we found that their implementation had a positive impact on its parameters. This statement was necessary to evaluate from the point of view of process performance indicators and from the economic point of view through the costs of non-conformance of furniture parts. The evaluation according to the process performance indicators is given in Table 4.

Table 4 | The evaluation of performance indicators of the hole drilling process

\begin{tabular}{cccc}
\hline The state & DPMO & The efficiency \% & The level sigma \\
\hline The original state & 224249.17 & 77.57 & 2.30 \\
The current state & 139566.84 & 85.40 & 2.61 \\
\hline
\end{tabular}

Source: own processing

Table 4 shows that the DPMO value decreased by $37.77 \%$ due to the effectiveness of corrective measures and the reduction of the number of non-conforming parts by 719 pieces per month. The average efficiency of the process increased by $10.09 \%$ and the average value of the sigma level by $13.48 \%$ compared to the original state of performance of the hole drilling process. These results are also confirmed by a comparison of the resulting values of the capability indices, which have increased. The $\mathrm{Cp}$ index, which was 0.16 , increased to 0.45 , and the Cpk index from 0.06 to 0.39 . Although the values of both coefficients have increased, they are still less than 1, which means the incapability of the process of drilling holes. Adherence to the upper and lower tolerance limits of the process was positive after the introduction of corrective measures. It can be stated that the project goal defined to reduce DPMO, efficiency and increase the sigma level by $10 \%$ was met.

The economic evaluation of the proposal for the implementation of the SS and LSS methodology was focused exclusively on the evaluation of the results concerning nonconforming furniture parts. We did not consider the costs associated with the measurement. In this analysis, these costs were considered negligible. The data for the economic evaluation of the proposal was the number of pieces of non-conforming furniture parts before and after the steps to improve the process in the critical process. The data on the number of non-conformities were for the production batch of 305,660 pieces, which were produced for one month, and for the average daily output of one drilling machine, 9,860 pieces of furniture parts.

Table 5 | The economic evaluation of the costs of non-conforming parts

\begin{tabular}{lccccc}
\hline The state & $\begin{array}{c}\text { The number of } \\
\text { non-conforming } \\
\text { parts (pcs) }\end{array}$ & The price $(€)$ & $\begin{array}{c}\text { The total } \\
\text { amount }(€)\end{array}$ & $\begin{array}{c}\text { The percentage of } \\
\text { non-conforming } \\
\text { parts (\%) }\end{array}$ \\
\hline $\begin{array}{l}\text { The } \\
\text { state } \\
\text { The } \\
\text { state }\end{array}$ & 1904 & 17,32 & 32977.28 & 0.63 \\
\hline
\end{tabular}

Source: own processing 
In the economic evaluation of the costs of non-conforming parts (Table 5) in the critical process, the market price of the furniture part was calculated to be $€ 17.32$. The price includes direct material and wage costs, other direct costs as statutory social insurance from direct wages, and an aliquot amount of production, administrative and sales overheads. The reduction of waste and thus the reduction of costs for non-conforming furniture parts reached the value of $37.76 \%$, thus fulfilling another goal of the project charter.

Hypothesis H2: The implementation of selected methods and tools to improve the quality and process performance will have a positive impact on the parameters of the critical process was confirmed based on positive results of the analysis of DPMO, efficiency, sigma level, capability indexes and economic evaluation of the cost of non-conforming products in the hole drilling process.

\subsection{The verification of hypothesis $\mathrm{H} 3$}

Verification of hypothesis $\mathrm{H} 3$ was performed using a paired T-test. Output Table 7 shows the arithmetic averages and standard deviations of the selection of hole drilling diameter values before and after corrective action, the difference in arithmetic averages, SD standard deviation, SDD standard deviation of the difference, t-test criterion value, $p$ significance level, as well as $95 \%$ - confidence intervals for the value of the difference of arithmetic averages.

Table 6 | The paired t-test for the hole diameters in furniture parts

\begin{tabular}{ccccccccc}
\hline $\begin{array}{c}\text { The } \\
\text { variable } \begin{array}{c}\text { The } \\
\text { arithmetic } \\
\text { average } \\
\text { of the } \\
\text { hole } \\
\text { diameters }\end{array}\end{array} \quad$ SD & $\begin{array}{c}\text { The } \\
\text { differe } \\
\text { nce }\end{array}$ & SDD & t & p & $\begin{array}{c}\text { The } \\
\text { confidence } \\
\text { interval } \\
-95.00 \%\end{array}$ & $\begin{array}{c}\text { The confidence } \\
\text { interval } \\
+95.00 \%\end{array}$ \\
\hline $\begin{array}{c}\text { before } \\
\text { change } \\
\text { after } \\
\text { change }\end{array}$ & 20.28 & 0.54 & & & & & & \\
\hline
\end{tabular}

Source: own processing

Table 6 shows that there were positive changes in the measured values of the critical process parameter, which was defined at the level of $20.00 \mathrm{~mm}$ with an upper and lower tolerance of $\pm 0.20 \mathrm{~mm}$. The hole diameter after the change recorded a value of $20.03 \mathrm{~mm}$, which means approaching the defined level of the parameter. At the same time, the standard deviation value was reduced from 0.54 to 0.21 , indicating that the values of the set of individual diameters were scattered around the arithmetic averages of the drilled hole diameters after implementing corrective measures. In general, it can be stated with 95\% confidence that the difference in arithmetic averages will range from 0.13 to $0.35 \mathrm{~mm}$. A graphical representation of the positive development in the variability and variance of the values of the hole drilling diameter before and after the corrective measures can be seen in the graph in Figure 1. 


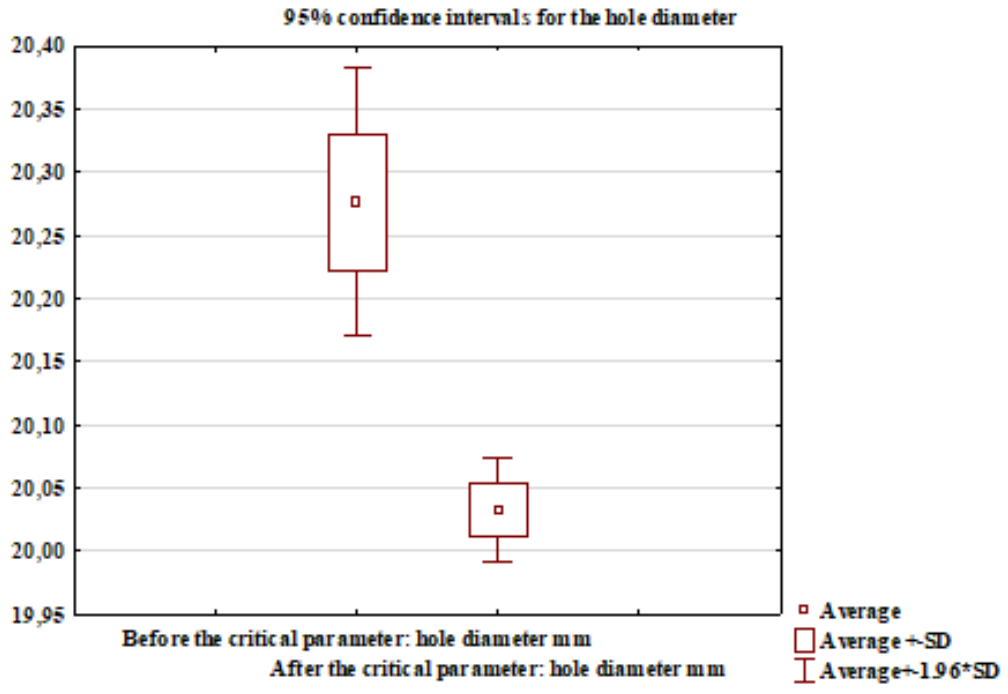

Figure 1 | Box chart of the hole diameters

Table 7 shows the arithmetic averages and SD - standard deviations of the selections of the efficacy values before and after corrective measure, the difference in arithmetic averages, the SDD - standard deviation of the difference, $t$ - the test criterion value, $p$ - the significance level, as well as the $95 \%$ confidence interval for the value of arithmetic averages difference.

Table 7 | The paired t-test for the efficiency of the hole drilling process

\begin{tabular}{|c|c|c|c|c|c|c|c|c|}
\hline $\begin{array}{c}\text { The } \\
\text { variable }\end{array}$ & $\begin{array}{l}\text { The } \\
\text { arithmetic } \\
\text { average } \\
\text { of the } \\
\text { efficiency }\end{array}$ & SD & $\begin{array}{c}\text { The } \\
\text { differe } \\
\text { nce }\end{array}$ & SDD & $t$ & p & $\begin{array}{c}\text { The } \\
\text { confidence } \\
\text { interval } \\
-95.00 \%\end{array}$ & $\begin{array}{c}\text { The confidence } \\
\text { interval } \\
+95.00 \%\end{array}$ \\
\hline $\begin{array}{l}\text { before } \\
\text { change }\end{array}$ & 0.7775 & 0.10 & & & & & & \\
\hline $\begin{array}{c}\text { after } \\
\text { change }\end{array}$ & 0.8539 & 0.06 & -0.08 & 0.07 & -0.65 & 0.000 & -0.1022 & -0.0542 \\
\hline
\end{tabular}

Source: own processing 
According to the results shown in Table 7, we can state that positive changes occurred in the efficiency values of the critical process, which was calculated and depends on the number of nonconformities in the process and subsequently on the number of defects that occur per million opportunities in the critical process. The efficiency value of the hole drilling process after the change increased to $85.39 \%$ compared to the efficiency of $77.75 \%$ before corrective measures were taken, which means that the efficiency set values were scattered around the arithmetic average of the efficiency values after the implementation of corrective measures. In general, we can state with 95\% confidence that the difference in arithmetic averages of efficiency will range from $5.42 \%$ to $10.22 \%$. A graphical representation of the positive development in the variance of efficiency values before and after the application of corrective measures can also be seen in the graph in Figure 2.

Box chart

$95 \%$ confindence intervals for the efficiency

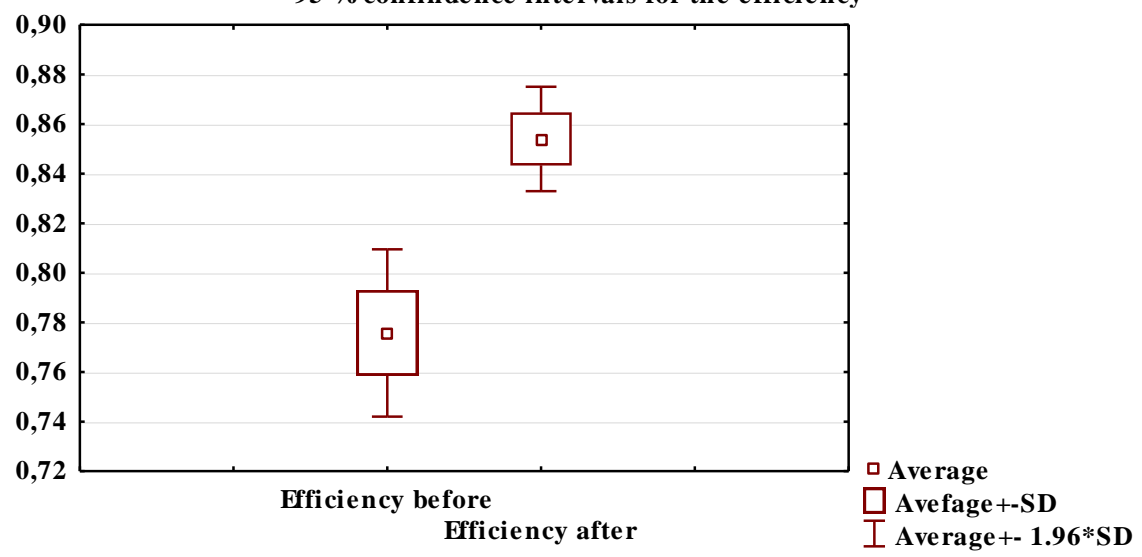

\section{Figure 2 | Box chart of efficiency}

Hypothesis H3: There is a significant dependence between the critical parameters of the furniture production process, and its performance was confirmed based on statistical results of the analysis of critical parameters of the furniture production process - drilling holes on parts and the performance of this process represented by the efficiency of the process.

\subsection{The model of application of methods and tools for performance management of furniture production processes}

It was possible to create a model of application of methods and tools for continuous quality improvement and performance management of furniture manufacturing processes by applying methods and tools within the Six Sigma and Lean Six Sigma methodologies in the processes of furniture manufacturing enterprise and subsequent verification of hypotheses (Figure 3).

In the Define phase, it was recommended to focus on activities such as the analysis of waste in the processes, whether from a material or time point of view. The transformation of the customer's voice $\mathrm{VoC}$ and its specific requirements through the method $\mathrm{CTQ}$ as 
process output parameters from the customer's point of view are suitable methods for subsequent determination of critical process indicators. The use of the QFD method was a suitable method for displaying the transformation of customer requirements into a product and comparison with the competition. Tables with data on the registration of nonconforming products, a reworking of non-conforming parts, records of downtimes and machine conversions are important primary sources of information on processes. Their further processing with the support of Six Sigma industrial statistics modules, as well as the representation of changes over a period using graphical methods, is used to identify critical processes and compare indicators of the number of DPMO, process efficiency and sigma process levels. The Pareto diagram was a suitable tool for determining the priority causes that affect process performance. Through the project charter, a plan was presented with the identification of the critical process problem, the definition of the project goal, specific breakdown of activities for team members, deadlines for implementation, inspections, revisions, implementation of corrective measures, limitation of team members' working hours, etc. Clearly and precisely defined requirements of the project charter simplified the administration in solving projects. Process maps and the SIPOC map were graphical methods that allowed a brief and illustrative description of processes.

In the Measure phase, the definition of key indicators of the critical process and the determination of the measurement plan according to Pande et al. (2002). The application of a measurement plan to obtain initial data for measuring process capability, calculations of capability indexes through industrial statistics \& Sigma process analysis, graphical representation via histograms and control diagrams formed the essence of the process of measuring process performance.

The Analyse phase was primarily focused on the analysis of identified non-conforming products, DPMO, and efficiency values of furniture production processes, levels of sigma processes, and measurement results. For further process analyses, methods and tools were proposed, such as the Ishikawa diagram for decomposing the first-degree causes into the second and third-degree causes, the affinity diagram for identifying causes in a broader context, analysis of possible defects and their consequences, FMEA, Pareto diagram for identifying and prioritising the problems, and the flowchart for showing the individual steps of analysing the causes of the problems. Brainstorming, as a highly operational method based on the principle of collective discussion, was recommended for the thorough specification and description of the problem with the participation of team members in various management positions. The Delphi method was also included in the model for forecasting and qualified opinions outside the direct participants of the project. It is based on written questions about the solved problems from experts from the external environment.

The Improve phase was characterised by proposals for corrective measures to eliminate the causes of problems. Methods aimed at improving processes, such as the reaction plan, the $8 \mathrm{D}$ method, and the value stream map, represent the improvement phase. The reaction plan for setting critical process values with instructions for machine operators and classification to reduce material waste, as well as the $8 \mathrm{D}$ method - report ensuring the relevance of data in solving problems, making decisions on measures to eliminate nonconforming products, planning, and securing them in terms of material, personnel, and time, have been transformed into standards for process performance management. The value stream map as a graphical method was used to display time, material, information, and 
information about the process. The verification of the results of corrective measures was by methods of analysis and synthesis, industrial statistics \& Sigma process analysis.

In the Control phase, increased attention was paid to the control of the qualitative results of changes and the introduction of new management concepts. The use of primary information from the record of non-conforming products and their subsequent transformation into DPMO indicators, efficiency indicators, and sigma levels collect initial information on the status of process performance, efficacy and results of corrective measures taken. In the Control phase, high demands were placed on employees of all levels of management. Wellorganised information and decision-making steps from the machine operator to the general manager are essential for quick and timely problem-solving. The above attributes are met by the model of the process of escalation of problems with a clear indication of personnel positions, information, and decision-making steps, as well as time limits of individual steps of problem-solving. An affinity diagram was designed to identify logical and causal relationships in addressing quality and performance issues from a broader perspective. Other recommended methods were the $5 S$ method for work organisation and work environment improvement and work standards for standardisation of work, SMED method for shortening tool change, TPM concept for improving maintenance management, Kaizen method to reduce deviations in processes related to quality, uptime, productivity, delivery, Andon method of warning system for immediate visual or auditory warning of deviations from normal, Poka-Yoke for defect prevention through sensors and debugging caused by employees, Kaizen to solve the problems of implementing a corporate culture of acknowledging the presence of problems, as Kanban to control production, the entire production flow of material, passing information between individual sections of production to satisfying customer needs. The purpose of using the methods recommended for monitoring critical process indicators through process capability indexes, customer requirements through VOC, CTQ, QFD, methods, and tools such affinity diagram, Ishikawa diagram, and non-conforming products record table was described in previous phases of DMAIC.

\section{Discussion}

The research aimed to determine the impact of the use of concepts, methods, and tools for continuous improvement of furniture processes to increase their capability and performance.

Results of the primary quantitative survey showed that using Six Sigma and Lean Six Sigma concepts are connected with business performance, and their use was found in furniture enterprises with higher levels of ROE indicator. On the other hand, only a few furniture enterprises have implemented SS and LSS concepts. The quantitative survey doesn't allow to find out if all enterprises have the same understanding of surveyed methods. Further qualitative research would be needed to solve this issue.

By creating a model of application of methods and tools, the application and verification of methods, tools, and procedures in solving the issue of process competence were clarified on specific examples from the real environment of furniture processes. Based on the achieved results of the analyses of DPMO, efficiency and Sigma level, economic analysis, and statistical analyses, we can assume that the use of concepts, methods and tools for quality improvement of furniture processes increases process performance. By applying the concepts of SS and LSS in specific processes of furniture production, we can agree with 
the statement (Šmída, 2007) that the interconnection of strategic and operational levels of management has a direct impact on performance. Focusing on Lean Manufacturing as an approach to improve performance by eliminating waste, whether in material, space, time, increase customer value. Authors such as Shah and Ward (2003) recommend different procedures and their combinations in lean manufacturing, including SS and LSS concepts using DMAIC. The mentioned concepts formed the pillar of the solution of the goal of this research and their practical application. The 5S method, Standard Work, and TPM have already been introduced in the enterprise, so we did not devote more space to those but were included in the model. Approaches and systems such as Poka-Yoke, Andon, Kanban, Kaizen, 5S method, Standard Work, SMED, TPM, VRK based on available guidance sources (Gnanaraj et al., 2012, Vinodh et al., 2012) were also included in the model to expand the portfolio of method selection. Studies by authors such as Inal Tamer et al. (2018), Smetkowska and Mrugalska (2018) report how SS improves the quality and performance of processes. These observations were also confirmed on the basis of the results of the analyses of the evaluation of processes in the furniture industry presented in this article. The established research hypotheses were confirmed, which means that the implementation of selected methods and tools for process performance management within the SS and LSS concepts has a positive impact on critical process parameters. These results were found on the basis of analysis of DPMO results, efficiency, sigma levels, capability indexes, and economic evaluation in the critical process, as well as statistical results of the analysis of critical parameters of the hole drilling process on furniture parts and its performance represented by process efficacy. At the same time, it should be noted that the application of SS and LSS in continuous improvement, optimisation of process performance is closely linked to the qualification structure of human resources at various levels of management. The success of the application of these concepts would not have been achieved without the support of the enterprise's management, managers and the cooperation of technicians, operators, and equipment operators. Similarly to the results of the study of Brun (2011) and Desai et al. (2012), it also can be stated that SS and LSS applications also reflect the size of the enterprises. For this reason, the proposed model provides enterprises with a choice of methods and approaches within DMAIC steps concerning the enterprise's size, capacity, and hierarchy of process management and employees' training.

Through the application of the methodological procedure of the DMAIC model, it was possible to determine and quantify the main defects and wastes, analyse the causes and establish improvement actions in the palletising process in the company, resulting in a $40 \%$ reduction in the handling of the supply operators in the company's shipping area, the elimination of the lack of pallets in the shipping process, the elimination of solid waste disposal in the environment and the reduction of expenses with pallets by $56 \%$ in the company (Barreiros \& da Silva, 2020). The iLeanDMAIC methodology was validated in the sector of other woodworks. Results using iLeanDMAIC allowed a reduction time in changeover in the assembly machine (from $39 \mathrm{~min}$ to $17 \mathrm{~min}$ ), presenting this a $44 \%$ gain on manufacture. iLeanDMAIC can help organisations thrive against their competitors, make their business more cost-effective and efficient (Ferreira et al., 2019). At the same time, it should be noted that the application of SS and LSS in process management is closely linked to the qualification structure of human resources at various levels of management, as well as to the qualification structure of human resources involved directly in the production 
process. The success of the application of these concepts would not be achieved without the support of the company's management, managers and cooperation of technicians, operators and operators who had knowledge of the methods used in the SS and LSS according to the hierarchical arrangement of personnel.

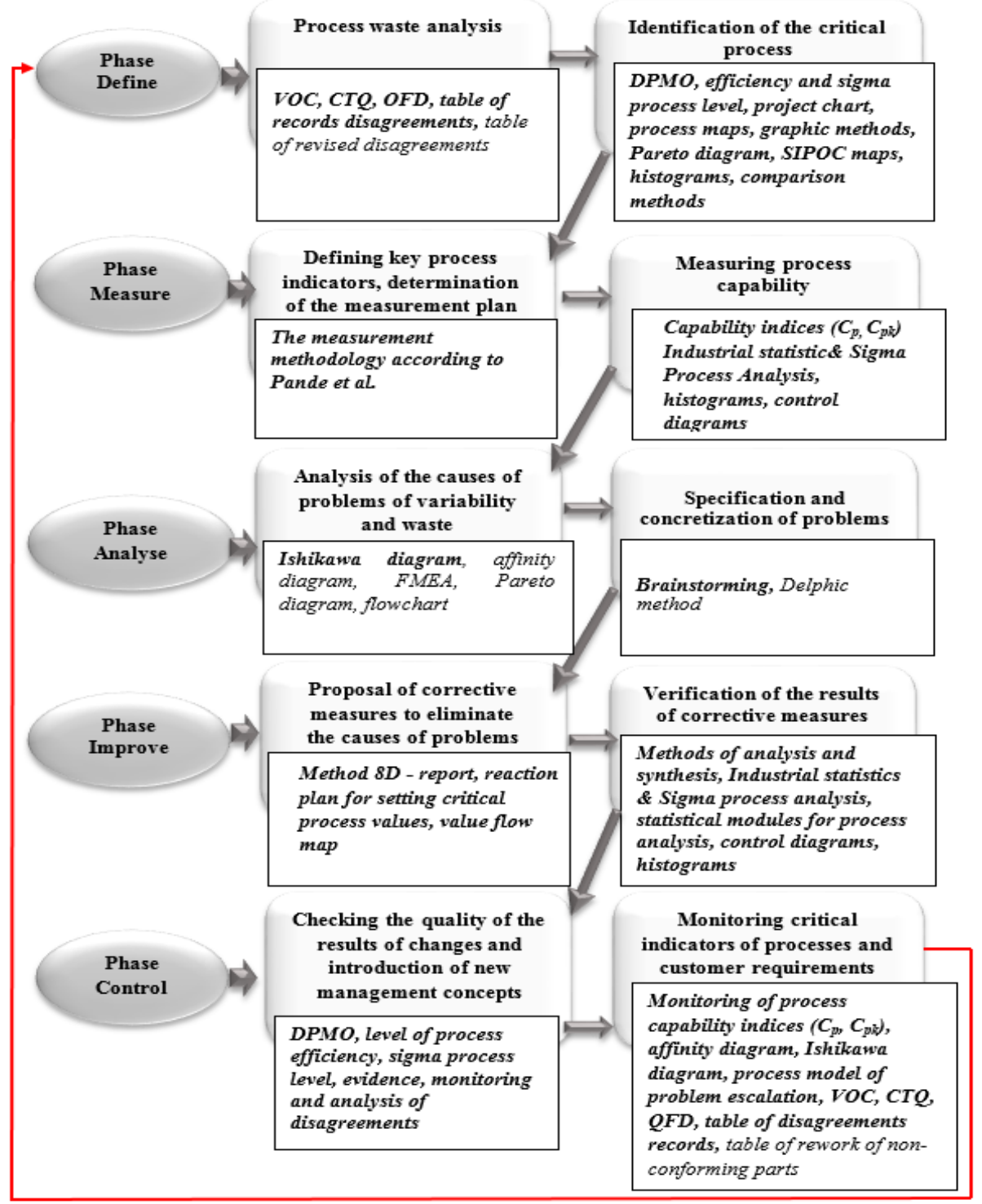

Figure 3 | Model of Six Sigma and Lean Six Sigma application in furniture processes 


\section{Conclusion}

Even setting the readiness to use new approaches and metrics among the enterprise's priorities is not a sufficient strategy in many respects. The results of the questionnaire survey supported by statistical processing of research results on the current state of the use of selected methods for continuous process improvement in enterprises with furniture production confirmed the impact on business performance. The enterprises using these methods are reaching higher performance.

The combination of theoretical knowledge focused on performance and quality of production processes and knowledge from the actual implementation of methods and tools for continuous improvement of furniture production processes in a particular company proved to be a good basis for creating a model within SS and LSS. These facts have contributed to the development of scientific knowledge in the field of the possibilities of using the SS and LSS concepts in furniture production processes.

The application of methods, tools, and procedures in solving the issue of capability processes was verified on specific examples from the real environment of furniture production. At the same time, it is expected to increase the level of education of employees in the field of information acquisition and processing, the use of methods and procedures for measuring processes. The teamwork will also be supported. The presentation of the application of methods and tools within SS and LSS will provide instructions for the use of new management methods. The experience has gained in creating a model design entitles us to express the opinion that these concepts should be implemented in furniture manufacturing processes, which would improve the quality of process parameters, as well as increase their performance. The approach of the enterprise's management in the adoption of the philosophy of using new approaches to continuous improvement of processes and its subsequent presentation at lower levels of management is a limiting factor in the implementation of the proposed model in other enterprises.

The specific outputs of the research work presented in the article improve defining problems, measuring process parameters, analysis of measured data, improving furniture production processes. Partial results of primary research offer opportunities for further research aimed at further investigation of causes and consequences affecting successful implementation of new approaches, but also of other enterprises of the wood processing industry as a whole.

\section{Acknowledgement}

This paper is the partial result of project No. 005TU Z-4/2020 under the KEGA agency, Slovakia. 


\section{References}

Albliwi, S., Jiju, A., Sarina, L., \& Ton, W. (2014). Critical failure factors of Lean Six Sigma: a systematic literature review. International Journal of Quality \& Reliability Management, 31,1012-1030. https://doi.org/10.1108/lJQRM-09-2013-0147.

Alhuraish, I., Robledo, C., \& Kobi, A. (2017). A comparative exploration of lean manufacturing and six sigma terms of their critical success factors. Journal of Cleaner Production, 164, 325-337. https://doi.org/10.1016/j.jclepro.2017.06.146.

Ambekar, S., \& Hudnurkar, M. (2017). Factorial structure for Six Sigma project barriers in Indian manufacturing and service industries. The TQM Journal, 29(5), 744-759. https://doi.org/10.1108/TQM-02-2017-0021.

Anand, G., \& Gray, J. V. (2017). Strategy and organisation research in operations management. Journal of Operations Management, 53/56, 1-8. https://doi.org/10.1016/j.jom.2017.09.001.

Antony, J., Ghadge, A., Ashby, S., \& Cudney, E. A. (2018). Lean Six Sigma journey in a UK higher education institute: a case study. International Journal of Quality and Reliability Management, 35(2), 510-526. https://doi.org/10.1108/IJQRM-01-2017-0005.

Antony, J., Rodgers, B., \& Cudney, E. A. (2017a). Lean Six Sigma for public sector organisations: is it a myth or reality?" International Journal of Quality and Reliability Management, 34(9), 1402 1411. https://doi.org/10.1108/IJQRM-08-2016-0127.

Antony, J., Rodgers, B., \& Cudney, E. A. (2017b). Lean Six Sigma in policing services: case examples, lessons learnt and directions for future research. Total Quality Management \& Business Excellence, 30(5-6), 1-13. https://doi.org/10.1080/14783363.2017.132 7319.

Antony, J., Rodgers, B., \& Gijo, E. V. (2016). Can Lean Six Sigma make UK public sector organisations more efficient and effective? International Journal of Productivity and Performance Management, 65(7), 995-1002. https://doi.org/10.1108/IJPPM-03-2016-0069.

Barreiros, N. R., \& da Silva, H. E. N. (2020). Methodological procedure for applying DMAIC model of six sigma methodology in a beverage company: a case study. International Journal for Innovation Education and Research, 8(4), 51-73. https://doi.org/10.31686/ijier.vol8.iss4.2258.

Brun, A. (2011). Critical success factors of six sigma implementations in Italian companies. International Journal of Production Economics, 131(1), 158-164. https://doi.org/10.1016/j.ijpe.2010.05.008.

Bryan, R., Antony, J., He, Z., Cudney, E., \& Laux, Ch. (2019). A Directed Content Analysis of Viewpoints on the Changing Patterns of Lean Six Sigma Research. The TQM Journal, 31. 641654. https://doi.org. /10.1108/TQM-03-2019-0089.

Chakravorty, S. S. (2009). Six Sigma failures: An escalation model, Operation Management Research. 2(1), 44-55. https://doi.org/10.1007/s12063-009-0020-8.

Choo, A. S. (2019). Solving Problems Efficiently in R\&D Projects: An Empirical Study of the Application of Six Sigma Tools in an Industrial Research Center. IEEE Transaction on Engineering Management, pp.1-14. https://doi.org/10.1109/tem.2019.2941942.

Chow, A. T., \& Moseley, J. L. (2017). Comparisons of six Sigma, lean, and human performance technology/performance improvement. Performance Improvement, 56(1), https://doi.org/10.1002/pfi.21677. 
de Koning, H., Does, R., \& Bisgaard, S. (2008). Generic Lean Six Sigma Project Definitions in Financial $\begin{array}{llll}\text { Services. Quality } \quad \text { Management } & \text { 32-45. }\end{array}$ https://doi.org/10.1080/10686967.2008.11918203

Desai, D. A., Antony, J., \& Patel, M. B. (2012). Six Sigma implementation in Indian industries: An assessment of the critical success factors for six sigma implementations in Indian industries. International Journal of Productivity and Performance Management, 61(4), 426-444. doi.org/ https://10.1108/17410401211212670.

Dora, M., \& Gellynck, X. (2015). Lean Six Sigma implementation in a Food Processing SME: a case study. Quality and Reliability Engineering International, 35(7), 1151-1159. https://doi.org/10.1002/qre.1852.

Dumitrescu, C., \& Dumitrache, M. (2011). The Impact of Lean Six Sigma on the Overall Results of Companies," Economia. Seria Management, Faculty of Management, Academy of Economic Studies, Bucharest, Romania, 14(2), 535-544.

Ferreira, C., Sá, J. C., Ferreira, L. P., Lopes, M. P., Pereira, T., Ferreira, L. P., \& Silva, F. J. G. (2019). iLeanDMAIC - A methodology for implementing the lean tools. Procedia Manufacturing, 41, 1095-1102. https://doi.org/10.1016/j.promfg.2019.10.038.

Fullerton, R. R., Kennedy, F. A., \& Widener, S. K. (2014). Lean manufacturing and firm performance: The incremental contribution of lean management accounting practices. Journal of Operation Management, 32(7-8), 414-428. https://doi.org/10.1016/j.jom.2014.09.002.

Garcia-Alcaraz, J., Avelar-Sosa, L., Latorre-Biel, J., Jiménez-Macías, E., \& Alor-Hernández, G. (2017). Role of human knowledge and communication on operational benefits gained from six sigma. Sustainability, 9(10), 1721. https://doi.org/10.3390/su9101721.

George, M. (2003). Lean Six Sigma for Service: How to Use Lean Speed and Six Sigma Quality to Improve Services and Transactions. 400. McGraw-Hill Education.

Gijo, E. V., \& Sarkar, A. (2013). Application of Six Sigma to improve the quality of the road for wind $\begin{array}{llll}\text { turbine installation. The } & \text { 244-258. }\end{array}$ https://doi.org/10.1108/17542731311307438.

Gijo, E. V., \& Antony, J. (2014). Reducing patient waiting time in outpatient department using lean six sigma methodology. Quality and Reliability Engineering International, 30(8), 1481-1491. https//doi.org/10.1002/qre.1552.

Gnanaraj, S., Michael, S., Devadasan, R., Murugesh, R., \& Sreenivasa, C. G. (2012). Sensitisation of SMEs towards the implementation of Lean Six Sigma - an initialisation in a cylinder frame manufacturing Indian SME. Production Planning \& Control: The Management of Operations, 23(8), 599-608. https://doi.org/10.1080/09537287.2011.572091.

Gogus, A. (2012). Brainstorming and Learning. Seel NM (eds) Encyclopedia of the Sciences of Learning. Springer, Boston, MA. https://doi.org/10.1007/978-1-4419-1428-6_491.

Han, X., Wen, Y., \& Kant, S. (2009). The global competitiveness of the Chinese wooden furniture industry. Forest Policy and Economics, 11(8), 561-569

Hlaváčková, P., \& Šafařík, D. (2014). Problems of Czech wood processing companies and indicators of competitiveness. Management of Companies, 4(1), 3-8

Hitt, M. A., Carnes, C. M., \& Xu, K. (2016). A current view of resource-based theory in operations management: a response to Bromiley and Rau. Journal of Operations Management, 41(10), 107-109. https://doi.org/10.1016/j.jom.2015.11.004. 
Inal Tamer, C., Goruroglu Ozturk, O., Kibar, F., Cetiner, S., Matyar, S., Daglioglu, G., \& Yaman, A. (2018). Lean six sigma methodologies improve clinical laboratory efficiency and reduce turnaround times. Journal of Clinical Laboratory Analysis, 32(1), 1-5. https://doi.org/10.1002/ jcla.22180.

Košturiak, J., Marek, M., Boledovič, L'., \& Krištak, J. (2010). Kaizen best practice of Czech and Slovak companies. Brno: Computer, 234.

Krishnaiyer, K., \& Chen, F. F. (2017). A Cloud-based Kanban Decision Support System for Resource Scheduling \& Management. Procedia Manufacturing, 11, 1489-1494. https://doi.org. /10.1016/j.promfg.2017.07.280.

Kumar, M., Antony, J., Singh, R. K., Tiwari, M. K., \& Perry, D. (2006). Implementing the Lean Sigma framework in an Indian SME. Production Planning \& Control, 17(4), 407-423. https://doi.org/10.1080/09537280500483350.

Kumar, M., Khurshid, K. K., \& Waddell, D. (2014). Status of quality management practices in manufacturing SMEs: A comparative study between Australia and the UK. International Journal of Production Research, 52(21), 6482-6495. https://doi.org/10.1080/00207543.2014.948574.

Kumar, S. S., Satsangi, P. S., \& Prajapati, D. R. (2011). Six Sigma an excellent tool for process improvement - a case study. International Journal of Scientific \& Engineering Research, 2(9), $1-10$.

Laureani, A., \& Antony, J. (2017). Leadership characteristics for lean sig sigma. Total Quality Management \& Business Excellence, 28(3-4), 405-426. https://doi.org/10.1080/1478 3363.2015.1090291.

Laureani, A., \& Antony, J. (2019). Leadership and Lean Six Sigma: a systematic literature review. Total Quality Management \& Business Excellence, 30(1-2), 53-81 https://doi.org/10.1080/14783363.2017.1288565.

Laureani, A., \& Antony, J. (2015). Leadership characteristics for Lean Six Sigma. Total Quality Management and Business Excellence, 28(3-4), 405-426. https://doi.org/10.1080/14783363.2015.1090291

Laureani, A., Antony, J., \& Douglas, A. (2010). Lean Six Sigma in a call centre: a case study. International Journal of Productivity and Performance Management, 59(8), 757-768. https://doi.org/10.1108/17410401011089454.

Lazarevic, M., Mandic, J., Sremčev, N., Vukelic, D., \& Debevec, M. (2019). A Systematic Literature Review of Poka-Yoke and Novel Approach to Theoretical Aspects. Journal of Mechanical Engineering, 454-467. https://doi.org/10.5545/sv-jme.2019.6056.

Marzagão, D. S. L., \& Carvalho, M. M. (2016). Critical success factors for six sigma projects. International Journal Project Management, 34(8), 1505-1518. https://doi.org/10.1016/j. ijproman.2016.08.005.

McLean, R. S., Antony, J., \& Dahlgaard, J. J. (2017). Failure of Continuous Improvement initiatives in manufacturing environments: a systematic review of the evidence. Total Quality Management and Business Excellence, 28(3-4), 219-237. https://doi.org/10.1080/14783363.2015.1063414.

Merkechová, D., Tiráková, A., \& Stehlíková, B. (2011). Basic of statistics for teachers. 408. UKF Nitra.

Michinov, N. (2012). Is Electronic Brainstorming or Brainwriting the Best Way to Improve Creative Performance in Groups? An Overlooked Comparison of Two Idea-Generation Techniques. Journal of Applied Social Psychology, 42(S1), 222-243. https://doi.org/10.1111/j.15591816.2012.01024.x. 
Montgomery, D. C. (2016). Why do lean six sigma projects sometimes fail? Quality and Reliability Engineering International, 32(4), 1279. https://doi.org/10.1002/qre.2009.

Mustafa, Z., \& Jamaluddin, Z. (2017). Six sigma critical success factors in manufacturing industries. AIP Conference Proceedings, 1830, 1-8. https://doi.org/10.1063/1.4981004.

Nenadál, J., \& Plura, J. (2008). Modern quality management. Management Press.

Nenadál, J., Plura, J., Hutyra, M., \& Petříková, R. (2005). Basics of quality management. VŠB Technical University of Ostrava.

Nourelfath, M., Aldowaisan, T., \& Hassan, J. (2016). Evaluating six sigma failure rate for inverse gaussian cycle times. International Journal of Production Research, 24(20), 6092-6101. https://doi.org/10.1080/00207543.2016.1190880.

Pacáková, V., Labudová, V., Sipková, L'., Šoltés, E., \& Vojtková, M. (2018). Statistical Methods for Economists. Iura Edition.

Pamfilie, R., Draghici, A. J. P., \& Draghici, M. (2012). The Importance of Leadership in Driving a Strategic Lean Six Sigma Management. Procedia Social and Behavioural Sciences, 58, 187196. https://doi.org/10.1016/j.sbspro.2012.09.992.

Pande, P. S., Neumann, P. R., \& Cavanagh, R. R. (2002). We introduce the Six Sigma method. TwinsCom, Brno.

Papulová, Z., Papula, J., \& Oborilová, A. (2014). Process management. Kartprint.

Potkány, M., Gejdoš, M., \& Debnár, M. (2018). Sustainable Innovation Approach for Wood Quality Evaluation in Green Business. Sustainability, 10(9): 2984. https://doi.org/10.3390/su10092984.

Psomas, E. (2016). The underlying factorial structure and significance of the six sigma difficulties and critical success factors. The TQM Journal, 28(4), 530-546. https://doi.org/10.1108/TQM-042015-0049

Ratajczak, E. (2009). Foresight in the wood science and industry - research development scenarios in Poland till 2020. Drewno, 52(182), 143-136

Ratajczak-Mrozek, M., \& Herbeć, M. (2014). Network structures in the furniture industry - the industrial network approach. Drewno, 57(191), 27-44. https://doi.org/10.12841/wood.1644-3985.058.02

Rimančík, M. (2007). Statistic for practice. 200. Marián Rimančík, Košice.

Sachin, S., \& Dileeplal, J. (2017). Sigma methodology for improving manufacturing process in a foundry. International Journal of Advanced Engineering Research and Science, 4(5), 131-136. https://doi.org/10.22161/ijaers.4.5.21.

Salah, S., Rahim, A., \& Carretero, J. A. (2010). The integration of Lean management and Six Sigma. International Journal of Lean Six Sigma, 1(3), 249-274. https://doi.org/10.1108 /20401461011075035.

Schroeder, R. G., Linderman, K., Liedtke, C., \& Choo, A. S. (2008). Six Sigma: Definition and underlying theory. Journal of Operations Management, 26(4), 536-554. https://doi.org/10.1016/j.jom.2007.06.007.

Shah, R., \& Ward, P. T. (2003). Lean manufacturing: context, practice bundles, and performance. Journal of Operations Management, 21(2), 129-149. https://doi.org/10.1016/S02726963(02)00108-0. 
Smetkowska, M., \& Mrugalska, B. (2018). Using six sigma DMAIC to improve the quality of the production process, A case study. Procedia-Social Behavioural Sciences, 238, 590-596. https://doi.org/10.1016/j.sbspro.2018.04.039.

Šmída, F. (2007). Implementation and development of process management in the company. Grada.

Snee, R. D. (2010). Lean Six Sigma - getting better all the time. International Journal of Lean Six Sigma, 1(1), 9-29, https://doi.org/10.1108/20401461011033130.

Snee, R. D., \& Hoerl, R. W. (2007). Integrating Lean and Six Sigma - a holistic approach. ASQ Six Sigma Forum Magazine, 6(3), 15-21.

Sony, M., Antony, J., Park, S., \& Mutingi, M. (2020). Key Criticisms of Six Sigma: A Systematic Literature Review. IEEE Transactions on Engineering Management, 67(3), 950-962. https://doi.org/10.1109/TEM.2018.2889517.

Sujová, A., Hlaváčková, P., \& Marcineková, K. (2015a). The trade competitiveness of furniture products. Drewno, 58(195), 102-115. https://doi.org/10.12841/wood.1644-3985.104.09.

Sujová, A., \& Marcineková, K. (2015b). Modern Methods of Process Management Used in Slovak Enterprises. Procedia-Economics and Finance, 23, 889 - 893.

STATISTICA 12 CZ - Stat Soft. Inc. (2013).

Sunder, M. V. (2016). Rejects reduction in a retail bank using Lean Six Sigma. Production Planning \& Control, 27(14), 1131-1142. https://doi.org/10.1080/09537287.2016. 1187312.

Sunder, M. V. (2013). Synergies of Lean Six Sigma. IUP Journal of Operations Management, 12(1), 21-31.

Swarnakar, V., \& Vinodh, S. (2016). Deploying Lean Six Sigma framework in an automotive component manufacturing organisation. International Journal of Lean Six Sigma, 7, 267-293. https://doi.org/10.1108/IJLSS-06-2015-0023.

Terek, M., \& Hrnčiarová, L. (2004). Statistical quality management. lura Edition.

Thomas, A., Barton, R., \& Chuke-Okafor, C. (2009). Applying lean six Sigma in a small engineering company - A model for change. Journal of Manufacturing Technology Management, 20(1), 113-129. https://doi.org/10.1108/17410380910925433.

Tuček, D., \& Zámečník, R. (2007). Management and evaluation od business proces performance in the practice. UTB Zlín.

Vest, J. R., \& Gamm, L. D. (2009). A critical review of the research literature on Six Sigma, lean and supergroup's hardwiring excellence in the US. The need to demonstrate and communicate the effectiveness of transformation strategies in healthcare. Implementation Science, 4, 35. https://doi.org/10.1186/1748-5908-4-35.

Vinodh, S., \& Swarnakar, V. (2015). Lean Six Sigma project selection using hybrid approach based on Fuzzy Dematel-Anp-Topsis. International Journal of Lean Six Sigma, 6(4), 313-338. doi.org/10.1108/IJLSS-12-2014-0041Andruss, P. (2012). Secrets of the 10 Most-Trusted Brands. Retrieved November 10, 2011, from http://www.entrepreneur.com/article/223125.

Vinodh, S., Kumar, S. V., \& Vimal, K. E. K. (2012). Implementing Lean Sigma in an Indian rotary switches manufacturing organisation. Production Planning \& Control, 25(4), 288-302. https://doi.org/10.1080/09537287.2012.684726. 
Vinodh, S., Kumar, S. V., \& Vimal, K. E. K. (2014). Implementing Lean Sigma in an Indian rotary switches manufacturing organisation. Production Planning \& Control, 25 (4), 288-302. https://doi.org. /10.1080/09537287.2012.684726.

Youssouf, A., Rachid, Ch., \& Verzea, I. (2014). Contribution to the Optimisation of Strategy of Maintenance by Lean Six Sigma. Physics Procedia, 55, 512-518. https://doi.org./10.1016/j.phpro.2014.08.001.

Yusuf, Y., Gunasekaran, A., \& Dan, G. (2007). Implementation of TQM in China and Organizational Performance: An Empirical Investigation. Total Quality Management, 18(5), 509-530. https://doi.org/10.1080/14783360701239982.

The research article passed the review process. | Received: July 1, 2021; Revised: October 13, 2021; Accepted: November 2, 2021; Pre-published online: November 25, 2021; Published in the regular issue: March 16, 2022. 